\title{
A COMPARISON BETWEEN ORGANIC AND CONVENTIONALLY PRODUCED EGGS
}

\author{
TAGHREED A. HAFEZ*, HANAN A. EL- GHAYATY*, and AMAL A. MEGAHED ${ }^{* *}$ \\ * Animal Health Research Institute, Port-Said Laboratory, Department of Food Hygiene. \\ ** Animal Health Research Institute, Port-Said Laboratory, Department of Bacteriology.
}

\section{ABSTRACT}

Received at: 27/12/2012

Accepted: 21/1/2013
A study on eggs from both organic and conventional was conducted in order to compare between them. The eggs were evaluated for their physical quality, microbial load, and presence of antibiotic residues. The study revealed that eggs from organic system were smaller ( 47.8 vs. $64.3 \mathrm{~g}$ ) with yolk, albumen, and egg shell weights significantly lower than eggs from conventional system (15.2 vs. $19.2 \mathrm{~g}),(25.3 \mathrm{vs} .34 .1 \mathrm{~g})$, and (7.12 vs. $9.5 \mathrm{~g})$ respectively. The Yolk/albumen ratio being higher in the organic eggs ( 0.60 vs. 0.56$)$. The percentage of egg shell was not affected by the housing system (14.8 vs. $14.7 \%)$. The overall defects in conventional eggs was higher ( $40 \%$ vs. $16 \%$ ). The microbiological examination showed that total bacterial and total mold counts were significantly higher in organic eggs, with the shell having the highest and albumen having the lowest microbial load. Monitoring of antibiotic showed zero residues of antibiotics in organic eggs while $8 \%$ of conventional eggs had antibiotics residues.

Key words: Organic eggs, conventional eggs, antibiotic residues, microbial contamination.

\section{INTRODUCTION}

In recent years, raising demand for organic food has been noticed. According to the majority of consumers it is safe for the health and its benefits are nutritional values and tastefulness. Because the majority of consumers have lost some trust in food derived from conventional production due to the use of developing technology and policies providing for the intensive input use for the supply of food necessities. Furthermore, the production of organic food based on special standards is considered as environmentally friendly and devoid of artificial fertilizers (Kouba, 2003; Newerli-Guz and Śmiechowska, 2004).

Organic poultry cannot be given growth-producing hormones (which are prohibited in conventional systems as well) or antibiotics. The poultry may receive preventive medical care, such as vaccines, and dietary supplements of vitamins and minerals. They must be fed certified organic feed, free of animal byproducts, or feed on certified organic pasture if raised on a pastured system. Animals must have access to the outdoors, shade, exercise areas, fresh air, and direct sunlight suitable to their species and stage of production Organic eggs must be processed in plants that are certified to process organic eggs (Henry, 2002 and USDA 2009). In case of conventional production. Poultry producers routinely use medications such as antibiotics in feed or drinking water to treat disease or to prevent disease outbreak and as a growth promoter (Donoghue, 2003).

Use of Antibiotic that might result in deposition of residues in meat and eggs must not be permitted in food intended for human consumption. If use of antibiotics is necessary as in prevention and treatment of animal diseases, a withholding period must be observed until the residues are negligible or no longer detected. The use of antibiotics to bring about improved performance in growth and feed efficiency, to synchronize or control of reproductive cycle and breeding performance also often lead to harmful residual effects (Nisha, 2008).

Most organic products sell for a premium over comparable conventional products, due in part to higher production, processing, procurement, and distribution costs relative to those of conventional products. In addition, organically produced foods have extra costs associated with product certification and segregation that carry all the way through the food chain. High costs and shortages of organic feed grains, along with a lack of processing capacity, are limiting the short-term expansion of the organic egg sector (USDA, AMS, 2003). At the same time, a growing number of consumers cite concerns regarding health issues, the environment, and animal welfare as factors influencing their decisions to purchase organic eggs, and these individuals are 
willing to pay the price premiums demanded in the marketplace. The aim of this study is to compare between the organic and conventionally produced eggs from the points of: Physical quality of eggs, microbiological status, and the presence of antibiotic residues.

\section{MATERIALS and METHODS}

\section{1- Sampling:}

One hundred and fifty of freshly laid organic and conventional eggs (75 of each) were obtained from big supermarkets in Port-Said City. Freshly laid eggs means, not more than 24 hours from production. Twenty five batches of eggs from each type were examined. Each batch comprised 3 eggs (one for each of) physical quality examination, microbiological examination, and detection of antibiotic residues.

\section{2 - Physical quality of egg assessment:}

Egg quality was measured following standard procedures as described by (Monira et al., 2003 and Fayeye et al., 2005). The external egg quality traits investigated were, egg weight(g), shell texture, shell cleanness, and shell soundness. The shell texture was examined through palpation. Egg weight was examined using an electronic weight scale. Similarly, internal egg parameters which were measured included, shell weight $(\mathrm{g})$, general appearances of internal egg parts, smell, albumen weight $(\mathrm{g})$, and yolk weight $(\mathrm{g})$. Any abnormality or defects observed in the albumen and yolk were recorded.

\section{3 - Microbiological examination:}

3-1- Egg shells were tested by surface rinse method as described by (Moats, 1980).

3-2- After rinsing, egg surface was sterilized with sterile cotton wool soaked in ethanol $(70 \%)$. Sterile forceps were used to puncture the egg at the tip to create a small opening from where the albumen was carefully drained out leaving behind the yolk which was transferred into a sterile beaker and examined as described by Idowu et al. (2010).

3-3-Total bacterial count was performed according to (FDA, 2001a) and Total mould count was performed following (FDA, 2001b).

\section{4 - Detection of antibiotic residues:}

The antimicrobial screening of eggs was carried out using the disc diffusion method where Bacillus cereus (obtained from the Animal Health Research Institute, Agriculture Center, Egypt) was used as the test organism. An 18 hours culture of the test organism in $10 \mathrm{ml}$ nutrient broth was used to inoculate Mueller Hinton agar plates. The eggs were prepared as mentioned in (3-2) then sterile filter paper disc $0.6 \mathrm{~cm}$ in diameter was dipped into the homogenized egg yolk and placed gently on the Mueller Hinton agar plate that has already been inoculated with the test organism according to the method of (Shahid et al., 2007). This was incubated at $37^{\circ} \mathrm{c}$ for $24 \mathrm{~h}$ after which the plates were viewed for the presence or absence of zone of inhibition of the test organisms around the test and control discs. The difference between the diameter of zone of inhibition and that of the disc were calculated. Any disc with a difference of $1 \mathrm{~mm}$ or more was considered positive for the presence of antibiotic.

\section{5 - Statistical analysis:}

Data were submitted to calculation of means, and the least significant difference test $\mathrm{p} \leq 0.05$ (Draper and Smith, 1998). All statistical procedures were computed using the Microsoft Excel 2007 in order to compare the mean values of the investigated parameters.

\section{RESULTS}

Table 1: Effect of conventional and organic production on the physical egg quality.

\begin{tabular}{ccccccc}
\hline $\begin{array}{c}\text { Production } \\
\text { system }\end{array}$ & $\begin{array}{c}\text { Egg weight } \\
(\mathrm{g})\end{array}$ & $\begin{array}{c}\text { Egg shell } \\
(\mathrm{g})\end{array}$ & $\begin{array}{c}\text { Egg shell } \\
(\%)\end{array}$ & Albumen $(\mathrm{g})$ & Yolk $(\mathrm{g})$ & $\begin{array}{c}\text { Yolk/albumen } \\
(\%)\end{array}$ \\
\hline Organic & $47.8^{\mathrm{a}}$ & $7.12^{\mathrm{a}}$ & $14.8^{\mathrm{a}}$ & $25.3^{\mathrm{a}}$ & $15.2^{\mathrm{a}}$ & $0.60^{\mathrm{a}}$ \\
\hline Conventional & $64.3^{\mathrm{b}}$ & $9.5 \mathrm{~b}$ & $14.7^{\mathrm{a}}$ & $34.1^{\mathrm{b}}$ & $19.2^{\mathrm{b}}$ & $0.56^{\mathrm{b}}$ \\
\hline
\end{tabular}

Means in the same column with different superscripts are significantly different $(p \leq 0.05)$.

Table 2: General appearance and defects recorded external and internal the eggs $(n=25)$.

\begin{tabular}{ccccccc}
\hline $\begin{array}{c}\text { Production } \\
\text { system }\end{array}$ & $\begin{array}{c}\text { Rough } \\
\text { shell }\end{array}$ & $\begin{array}{c}\text { Dirty } \\
\text { shell }\end{array}$ & $\begin{array}{c}\text { Cracked } \\
\text { shell }\end{array}$ & Off odor & $\begin{array}{c}\text { Blood } \\
\text { spots }\end{array}$ & Total \\
\hline Organic & $2(8 \%)$ & $1(4 \%)$ & $0(0 \%)$ & $0(0 \%)$ & $1(4 \%)$ & $4(16 \%)$ \\
\hline Conventional & $4(16 \%)$ & $2(8 \%)$ & $0(0 \%)$ & $1(4 \%)$ & $3(12 \%)$ & $10(40 \%)$ \\
\hline
\end{tabular}


Table 3: Effect of conventional and organic production on egg's microbial load.

\begin{tabular}{ccccccc}
\hline \multirow{2}{*}{$\begin{array}{c}\text { Production } \\
\text { system }\end{array}$} & \multicolumn{3}{c}{ Total aerobic bacterial count } & \multicolumn{3}{c}{ Total mould count } \\
\cline { 2 - 7 } & Egg shell & Yolk & Albumen & Egg shell & Yolk & Albumen \\
\hline Organic & $7.5 \times 10^{5 \mathrm{a}}$ & $7.7 \times 10^{1 \mathrm{a}}$ & $1.6 \times 10^{1 \mathrm{a}}$ & $6.1 \times 10^{3 \mathrm{a}}$ & $2.7 \times 10^{1 \mathrm{a}}$ & $1.3 \times 10^{1 \mathrm{a}}$ \\
\hline Conventional & $5.6 \times 10^{4 \mathrm{~b}}$ & $3.5 \times 10^{1 \mathrm{~b}}$ & $1.3 \times 10^{1 \mathrm{a}}$ & $3.4 \times 10^{3 \mathrm{~b}}$ & $1.5 \times 10^{1 \mathrm{~b}}$ & $1.1 \times 10^{\mathrm{aa}}$ \\
\hline
\end{tabular}

Means in the same column with different superscripts are significantly different $(p \leq 0.05)$.

Table 4: Incidences of antibiotic residues in organic and conventionally produced eggs $(n=25)$.

\begin{tabular}{ccl}
\hline Production system & No. & $\%$ \\
\hline Organic & 0 & 0 \\
\hline Conventional & 2 & 8 \\
\hline
\end{tabular}

\section{DISCUSSION}

The results of the current study gave information on the physical quality characteristics of organic and conventional eggs. The physical appearance of an egg makes the first impression upon the consumer. If the product does not meet perceived expectations, consumer confidence diminishes. Therefore external and internal characteristic of eggs prerequisite for safety, soundness and wholesomeness of the eggs. The data in (Table 1 and Table 2) listed these characteristics. (Table 1) indicated that eggs from organic system were smaller (47.8 vs. $64.3 \mathrm{~g}$ ) with yolk, albumen, and egg shell weights significantly lower than eggs from conventional system (15.2 vs. $19.2 \mathrm{~g}),(25.3$ vs. $34.1 \mathrm{~g})$, and (7.12 vs. $9.5 \mathrm{~g})$ respectively. While the Yolk/albumen ratio being higher in the organic eggs $(0.60$ vs. 0.56$)$. The percentage of egg shell was not affected by the housing system (14.8 vs. $14.7 \%)$. These results are coming in parallel with Cherian et al. (2002); Smiechowska and Dmowski (2005); Minelli et al. (2007). The overall defects prevalence in the organic eggs was $16 \%$. A higher prevalence of defected eggs was observed in eggs from the conventional system (40\%) (Table 2). Rough shell defect, dirty shell, off odor, and blood spots were higher in conventionally produced eggs (16 vs. $8 \%)$, ( 8 vs. $4 \%$ ), (4 vs. $0 \%)$, and (12 vs. 4\%) respectively. Rough shell eggs fracture more easily and have poor appearance. This defect may be hereditary Jacob et al. (2011). Dirty egg shell decreases the quality of eggs and in some areas as in United states, an egg with manure or adhering material on the shell cannot be marketed. It is classified as dirty and cannot be used for human consumption Jacob et al. (2011). Off odor defect was detected in $4 \%$ of the examined conventional eggs and not detected in the organic one. Off odor may become from chemicals used for treating parasites in the flocks Jacob et al. (2011). Blood spots are caused by rupture of small vessels while the eggs is being formed this defect may be due to genetic factors, stress during ovulation, vitamin $\mathrm{K}$ deficiency, and diseases Jordan and Pattison (1996); Seidler (2003); Jacob et al. (2011).

The results of the microbiological examination of the two types of eggs which are shown in (Table 3) reveal that total bacterial and total mold counts are significantly higher in organic eggs. The shell having the highest microbial load $\left(7.5 \times 10^{5}\right.$ vs. $\left.5.6 \times 10^{4} \mathrm{cfu} / \mathrm{g}\right)$ of $\mathrm{TBC}$ and $\left(6.1 \times 10^{3}\right.$ vs. $\left.3.4 \times 10^{3} \mathrm{cfu} / \mathrm{g}\right)$ of TMC. While the albumen having the lowest microbial load $\left(1.6 \times 10^{1} \mathrm{vs} .1 .3 \times 10^{1} \mathrm{cfu} / \mathrm{g}\right)$ and $\left(1.3 \times 10^{1} \mathrm{vs}\right.$. $\left.1.1 \times 10^{1} \mathrm{cfu} / \mathrm{g}\right)$ respectively. External eggshell contamination could be important for the shelf life and the food safety of consumption eggs and egg products. It is hypothesized that bacterial contamination of the internal egg content could be the result of the penetration of the shell by bacteria deposited on the surface of the egg after it has been laid (Schoeni et al., 1995; Smith et al., 2000). The interior of the newly laid eggs is usually free from micro-organisms but contamination of egg contents occasionally occurs either before the egg is laid or shortly after (Abdel-Hameed, 2009). The obtained results agreed with those of Schwaiger et al. (2008) and De Reu et al. (2008) who stated that conventionally produced eggs generally had lower bacterial count than the organic type. It is known that eggs from caged birds are less likely to be contaminated with various microorganisms this because the droppings fall through the cage floor do not come in contact with the eggs. Also, birds that are allowed to range outdoors are more likely to become contaminated from soil, insects, and rodent infestation. Therefore, organic eggs are more likely to be contaminated than eggs from conventional system (Board and Fuller 1994; Board and Tranter, 1995 and De Reu et al., 2008).

Antibiotics were used at low levels in poultry feed to enhance the health and productivity of flocks, 
facilitate the efficient production of poultry, allowing the consumer to purchase at a reasonable cost high quality meat and eggs Donoghue and Myers (2000); Schneider and Donoghue (2000). Concern over antibiotic residues in food of animal origin occurs in two times; one which produces potential threat to direct toxicity in human, second is whether the low levels of antibiotic exposure would result in alteration of microflora, cause disease and the possible development of resistant strains which cause failure of antibiotic therapy in clinical situations (Nisha, 2008). (Table 4) showed zero residues of antibiotics in organic eggs while $8 \%$ of conventional eggs had residues of antibiotics. In studies done by CFIA (2006) and DAFF (2010) eggs from different housing systems including organic and conventional systems were examined for a wide spectrum of antibiotics, zero residues were found. Because in these countries the use of antibiotics in feed is prohibited and its use is permitted only under veterinary supervision to treat clinical disease outbreaks. Eggs from treated hens cannot be offered for sale until the completion of withdrawal period to ensure that no residues are present in the eggs (Blair, 2012).

\section{REFERENCES}

Abdel-Hameed, K.G. and Laila Mostafa Elmalt (2009): Prevalence and Public Health Hazards of $S$. aureus Associated With Consumption of Hen's Eggs in Qena Governrate. Mansoura Vet. Med. J. , XI,(1): 41-49.

Blair, R. (2012): Organic production and Food quality: A Down to Earth Analysis, $1^{\text {st }}$ ed. Edited by John Wiley and Sons, UK.

Board, R.G. and Fuller, R.C. (1994): Microbiology of the avian egg. $1^{\text {st }}$ Ed. Chapman and Hall, pp. 94-128.

Board, R.G. and Tranter, H.S. (1995): The microbiology of eggs. In Egg Science and Technology, Standelman, W.J. and Cotterill, O.J. (Eds.), The Haworth Press, Inc. New York pp. 81-104.

CFIA (Canadian Food Inspection Agency) (2006): 2005-2006 National chemical residues monitoring program annual report. http//: www. Inspection.gc.ca.

Cherian, G.; Holsonbake, T.B. and Goeger, M.P. (2002): Fatty acid composition and egg components of specialty eggs. Poultry Science J., 81: 30-33.

DAFF (Department of Agriculture, Fisheries and Forestry) (2010): Australian National Residue Survey 2008-2009. http//:www.daff.gov.au/agriculturefood/nrs/animal2.

De Reu, K.; Messens, W.; Heyndrickx, M.; Rodenburg, T.B.; Uyttendaele, M. and Herman, L. (2008): Bacterial contamination of table eggs and influence of housing systems. World's Poultry Sc., 64: 5-19.

Donoghue, D.J. (2003): Antibiotic residues in poultry tissues and eggs: Human Health Concerns. Poult. Sci., 82: 618-621.

Donoghue, D.J. and Myers, K. (2000): Imaging residue transfer into eggs. J. Agric. Food Chem. 48: 6431-6434.

Draper, N.R. and Smith, H. (1998): Applied Regression Analysis. $3^{\text {rd }}$ Edn., John Wiley, New York, pp: 131-153.

Fayeye, T.R.; Adeshiyan, A.B. and Olugbami, A.A. (2005): Egg traits, hatchability and early growth performance of the Fulani-ecotype chicken Livestock. Research for Rural Development Volume 17, Article\# 8 Retived June 25, 2010, from http// www.Irrd.org

FDA (2001 a): BAM, Aearobic Plate Count. Bacteriological Analytical Manual, $8^{\text {th }}$ Ed., Rev. A, 1998. Chapter 3. Authors: Maturin L, and Peeler J. T.

FDA (2001b): Yeast, Mould and Mycotoxins. Bacteriological Analytical Manual, $8^{\text {th }}$ Ed., Rev. A, 1998. Chapter 18. Authors: Tournas V, Stack M.E., Mislivec P.B., and Bandler R.

Henry, R. (2002): Organic Poultry- Eggs. Martime Certified Organic Growers " Organic Farm Profiles" March 2002.

Idowu, F.; Junaid, K.; Paul, A.; Gabriel, O. and Paul, A. (2010): Antimicrobial screening of commercial eggs and determination of Tetracycline residue using two microbiological methods. Inter. J. Poult. Sci., 9(10): 959-962.

Jacob, J.P.; Miles, R.D. and Ben Mather, F. (2011): Egg quality. http//: WWW. Edis.ifas.ufl.edu.

Jordan, F.T.W. and Pattison, M. (1996): Poultry disease. $4^{\text {th }}$ ed. W B Saunders Company Ltd, London.

Kouba, M. (2003): Quality of organic animal products. Livest. Prod. Sci., , 80: 33-40.

Minelli, G.; Sirri, F.; Folegatti, E.; Meluzzi, A. and Franchini, A. (2007): Egg quality traits of laying hens reared in organic and conventional systems. Italian Journal of Animal Science 6: 728-730.

Moats, W.A. (1980): Classification of bacteria from commercial egg washers and

washed and unwashed eggs. J. Appl. Environ. Microbiol. 4: 710-714.

Monira, K.N.; Salahuddin, M. and Miah, G. (2003): Effect of breed and holding period on egg quality characteristics of chicken. Inter. J. Poult. Sci., 2: 261-263.

Nisha, A.R. (2008): Antibiotic Residues - A Global Health Hazard. Veterinary World, 1(12): 375377

Newerli-Guz, J. and Śmiechowska, M. (2004): Organic food advantages in consumer's opinion. Bromat. Chem. Toksykol., Suppl., 135-138. 
Schneider, M.J. and Donoghue, D.J. (2000): Analysis of fluoroquinolones antibiotics in eggs and chicken tissue using automated microdialysis liquid chromatography. Pages 998-1004 in Proceedings of the Euro Residue IV Conference: Residues of Veterinary Drugs in Food. National Institute of Public Health and the Environment (RIVM), Veldhoven, The Netherlands.

Schoeni, J.L.; Glass, K.A.; Mcdermott, J.L. and Wong, A.C.L. (1995): Growth and penetration of Salmonella enteritidis, Salmonella heidelberg and Salmonella typhimurium in eggs. International J. of Food Microbiol., 24: 385-396.

Schwaiger, K.; Schmied, E.M. and Bauer, J. (2008): Comparative analysis of antibiotic resistance characteristics of Gram-negative bacteria isolated from laying hens and eggs in conventional and organic keeping systems in Bavaria, Germany. Zoonoses Public Health j., 55(7): 331-341

Seidler, E. (2003): FAO. Egg marketing. A guid for the production and sale of eggs. Agricultural services Bulletin 150, Rome, Italy.
Shahid, M.A.; Siddique, M.; Reham, S.; Hameed, S. and Hussain, A. (2007): Evaluation of a microbiological growth inhibition assay as a screening test for the presence of antibiotic residues in poultry meat. Amer. J. Food Technol., 2: 457-461.

Smiechowska, M. and Dmowski, P. (2005): Influence of raising method on the quality of hen eggs. Polish Journal of Food and Nutrition Sciences, 14/55, SI 1: 117-120.

Smith, A.; Rose, S.P.; Wells, R.G. and Pirgozliev, V. (2000): The effect of changing the excreta moisture of caged laying hens on the excreta and microbial contamination of their egg shells. British Poultry Science, 41(2): 168-173.

USDA (U.S. Department of Agriculture) (2009): Organic Food Standards and Labels. The Facts. http//:www. Ams.usda.gav.

USDA, AMS (U.S. Department of Agriculture, Agricultural Marketing Service) (2003): Organic Feed for Poultry and Livestock: Availability and Prices. Agricultural Marketing Service, USDA. Available at http//: www.ams.usda.gov. 